\title{
Treating Arthritis With Locally Applied Heat or Cold
}

\author{
Fredrikus G.J. Oosterveld and Johannes J. Rasker
}

The scientific basis for the treatment of arthritis with locally applied heat or cold is reviewed. Experimental studies in vitro, in animals, in healthy subjects, and in patients are considered. Results of investigations of the effects of locally applied heat or cold on the deeper tissues of joints and on joint temperature in patients are not consistent. In general, locally applied heat increases and locally applied cold decreases the temperature of the skin, superficial and deeper tissues, and joint cavity. Most studies dealing with the effects of heat and cold on pain, joint stiffness, grip strength, and joint function in inflamed joints report beneficial effects. In vitro studies show that higher temperatures increase the breakdown of articular cartilage and tissues that contain collagen. Therefore, one goal of physical therapy should be to decrease intraarticular temperature in actively inflamed arthritic joints.

Copyright $(1994$ by W.B. Saunders Company

INDEX WORDS: Physiotherapy; thermotherapy; arthritis; osteoarthritis; heat; cold.

$\mathbf{T}$ HE THERAPEUTIC VALUE of heat and cold in rheumatic complaints was well known in ancient Greece and Rome. Both can relieve pain and diminish inflammatory symptoms, but the exact indications for thermotherapy remain unclear. The basis for its application in rheumatology is largely empirical. Therefore, we have reviewed the English, French, German, and Dutch literature.

\section{IN VITRO STUDIES}

In rheumatoid arthritis (RA) and active osteoarthritis (OA), destructive enzymes are produced in the inflamed joints. ${ }^{1-6}$ The activity of these cartilage-degrading enzymes, particularly collagenase, elastase, hyaluronidase, and protease, is influenced by local joint temperature. At temperatures of $30^{\circ} \mathrm{C}$ and below, the activity of destructive enzymes is negligible. ${ }^{3-5,7}$

From the Department of Rheumatology, Hospital Medisch Spectrum Twente, and the University Twente, Enschede, the Netherlands.

Supported by The Nationaal Reumafonds, the Netherlands.

Fredrikus G.J. Oosterveld, RPT: Physiotherapist; Johannes J. Rasker, MD, PhD: Consultant Rheumatologist and Professor, University Twente.

Address reprint requests to Fredrikus G.J. Oosterveld, RPT, Department of Rheumatology, Hospital Medisch Spectrum Twente, Postbus 50000, 7500 KA Enschede, the Netherlands. Copyright 1994 by W.B. Saunders Company

0049-0172/94/2402-0002\$5.00/0
Harris et al studied the influence of temperature on the activity of human rheumatoid synovial collagenase. ${ }^{7}$ They found that the destruction of cartilage by collagenase increased with increasing temperature. At temperatures found in knee joints affected by RA $\left( \pm 36^{\circ} \mathrm{C}\right)$, collagenolyses is four times greater than at temperatures normally found in healthy knee joints $\left( \pm 33^{\circ} \mathrm{C}\right) .{ }^{7}$ The synthesis rates of hyaluronic acid in cultures of normal and rheumatoid human synovial cells increase as local temperature increases from $32^{\circ} \mathrm{C}$ to $39^{\circ} \mathrm{C}$ and decrease sharply at $41^{\circ} \mathrm{C} .{ }^{8}$ In rabbit articular cartilage, temperatures above $38^{\circ} \mathrm{C}$ diminish metachromasia, reduce the rate of proteoglycan synthesis, and increase degradation of the macromolecules of the cartilage matrix. ${ }^{9}$

Ligaments in canine knee joints become increasingly lax as ambient temperature increases from $2^{\circ} \mathrm{C}$ to $37^{\circ} \mathrm{C}$ and undergo irreversible damage at $42^{\circ} \mathrm{C} .{ }^{10}$

\section{ANIMAL STUDIES}

In animal experiments, intraarticular temperature increases with application of superficial heat, microwave diathermy, short-wave diathermy, and ultrasound treatment. ${ }^{11-13}$ The superficial application of cold reduces intraarticular temperature. ${ }^{11,12,14}$ Temperatures in various tissues have been decreased by several cold stimuli $^{12,15}$ and increased by treatment with 
heat. ${ }^{12,13}$ Animal joint findings are summarized in Table 1.

In acute urate-induced synovitis in dogs, ice packs reduce joint temperature by $1.7^{\circ} \mathrm{C}$ and significantly $(P<.05)$ lower the number of granulocytes. Hot packs $\left(60^{\circ} \mathrm{C}\right)$ increase intraarticular temperature by $0.6^{\circ} \mathrm{C}$ and increase the number of granulocytes $(P<.05$, treated $v$ control). Synovial fluid volume and polymorphonuclear infiltration of urate-induced synovitis are decreased by cold and increased by heat. In chronic urate-induced synovitis in dogs, no significant changes are found after treatment with either heat or cold ${ }^{11}$ (Table 1).

In a histological study using 10 pigs, experimentally induced sprains of the radiocarpal ligament were treated by applying crushed-ice packs for 20 minutes, allowing 1 hour of rest, and then applying crushed-ice packs for another 20 minutes. ${ }^{16}$ This treatment increased swelling in the subcutaneous tissue but reduced posttraumatic inflammation as measured by counts of polymorphonuclear leukocytes, plasma cells, and lymphocytes and by the amount of fibrous exudate.

\section{STUDIES IN HEALTHY HUMAN SUBJECTS}

Few studies have dealt with intraarticular temperatures and changes induced by physiotherapy in healthy human subjects. In those that have, intraarticular temperatures in the shoulder, hip, knee, and ankle vary between $32.4^{\circ} \mathrm{C}$ $\left(\mathrm{SD}, 0.5^{\circ} \mathrm{C}\right)$ and $32.9^{\circ} \mathrm{C}\left(\mathrm{SD}, 0.9^{\circ} \mathrm{C}\right)^{17-20}$ (Table 2).

We recently evaluated the effects of several applications on the skin surface temperature and intraarticular temperature of the knee joint in 42 healthy volunteers. Mean skin surface temperature dropped by $16.4^{\circ} \mathrm{C}\left(\mathrm{SD}, 3.6^{\circ} \mathrm{C}\right)$ after application of ice chips and by $15.0^{\circ} \mathrm{C}(\mathrm{SD}$,

Table 1: Effects of Physiotherapy in Animals In Vivo

\begin{tabular}{|c|c|c|c|c|c|}
\hline Modality & Reference & $\begin{array}{l}\text { Animal } \\
\text { Model }\end{array}$ & $\begin{array}{c}\text { Change in } \\
\text { Tissue } \\
\text { Temperature } \\
\left({ }^{\circ} \mathrm{C}\right)\end{array}$ & $\begin{array}{c}\text { Change in } \\
\text { Muscle } \\
\text { Temperature } \\
\left({ }^{\circ} \mathrm{C}\right)\end{array}$ & $\begin{array}{c}\text { Change in } \\
\text { Intraarticular } \\
\text { Temperature } \\
\left({ }^{\circ} \mathrm{C}\right)\end{array}$ \\
\hline \multicolumn{6}{|c|}{ Normal joints; cold treatment } \\
\hline Ice & Wakim et al ${ }^{12 *}$ & Dog & -16.6 & -17.4 & -18.4 \\
\hline Ice & McMaster et al ${ }^{15} \dagger$ & Canine & & -11.3 & \\
\hline Cold pack & Kern et $\mathrm{al}^{14} \ddagger$ & Bull & & & -6.6 \\
\hline Colc pack & McMaster et $\mathrm{al}^{15} \dagger$ & Canine & & -8.4 & \\
\hline Chemical pack & McMaster et al ${ }^{15} \dagger$ & Canine & & -3.5 & \\
\hline Freon pack & McMaster et al ${ }^{15} \uparrow$ & Canine & & -1.7 & \\
\hline \multicolumn{6}{|c|}{ Normal joints; heat treatment } \\
\hline Hot pack & Wakim et al ${ }^{12 *}$ & Dog & +6.8 & +4.0 & +4.1 \\
\hline Microwave & Wakim et al ${ }^{12 *}$ & Dog & +4.9 & +3.0 & +6.0 \\
\hline Short-wave & Wakim et al ${ }^{12 *}$ & Dog & +2.9 & +2.4 & +2.8 \\
\hline Short-wave & Wakim et al ${ }^{12 *}$ & Dog & +4.1 & +1.9 & +3.3 \\
\hline \multirow[t]{3}{*}{ Ultrasound } & Lehman et al/ ${ }^{13 \xi}$ & Hog & +5.2 & +3.7 & +1.6 \\
\hline & & & +5.6 & & \\
\hline & & & +8.2 & & \\
\hline \multirow[t]{4}{*}{ Ultrasound } & Lehman et $a^{13 \xi}$ & $\mathrm{Hog}$ & +4.1 & +3.4 & \\
\hline & & & +6.4 & & \\
\hline & & & +9.3 & & \\
\hline & & & +2.3 & & \\
\hline \multicolumn{6}{|l|}{ Adjuvant arthritis } \\
\hline Ice & Dorwart et al ${ }^{11} \|$ & Dog & & & -1.7 \\
\hline Hot pack & Dorwart et al ${ }^{1} \|$ & Dog & & & +0.6 \\
\hline
\end{tabular}

* Measurements in subcutaneous tissues, adjacent muscles, knee joints of dogs. tMeasurements in thigh muscles of canines.

‡Measurements in carpal joints of young bulls.

§Measurements in subcutaneous tissues, adjacent muscles, and knee joints of hogs.

|Measurement in knee joints of dogs. 
Table 2: Intraarticular Temperature

\begin{tabular}{|c|c|c|c|}
\hline Subjects & Reference & Overall* & Knee \\
\hline Healthy & Haimovici et al 17,20 & $32.8(0.8)$ & $32.8(1.1)$ \\
\hline Healthy & Oosterveld et al ${ }^{18}$ & & $32.5(1.8)$ \\
\hline Healthy & Horvath et al ${ }^{19}$ & & $32.4(0.5)$ \\
\hline RA & Haimovici et al ${ }^{17,20}$ & $35.9(1.4)$ & $35.8(1.5)$ \\
\hline RA & Oosterveld et al ${ }^{37}$ & & $35.6(1.6)$ \\
\hline RA & Horvath ef al ${ }^{19}$ & & $34.1(1.6)$ \\
\hline OA & Haimovici ${ }^{20}$ & $33.0(0.9)$ & $32.9(0.9)$ \\
\hline Active OA & Horvath et al ${ }^{19}$ & & $34.4(0.5)$ \\
\hline Active OA & Haimovici ${ }^{20}$ & $36.0(1.0)$ & $36.1(1.2)$ \\
\hline $\begin{array}{l}\text { Posttraumatic } \\
\text { arthritis }\end{array}$ & Haimovici20 & $35.1(1.3)$ & $35.2(1.4)$ \\
\hline
\end{tabular}

NOTE. Mean (SD) temperature in degrees $C$.

Abbreviations: RA, rheumatoid arthritis; $O A$, osteoarthritis.

* Mean (SD) temperature in shoulder, hip, knee, and ankle.

$3.6^{\circ} \mathrm{C}$ ) after application of nitrogen cold air. Mean intraarticular temperature decreased by $9.4^{\circ} \mathrm{C}\left(\mathrm{SD}, 2.1^{\circ} \mathrm{C}\right)$ and $4.1^{\circ} \mathrm{C}\left(\mathrm{SD}, 0.9^{\circ} \mathrm{C}\right)$, respectively. Treatment with lignoparaffin increased the surface temperature by $2.4^{\circ} \mathrm{C}\left(\mathrm{SD}, 1.7^{\circ} \mathrm{C}\right)$ and temperature within the joint by $1.4^{\circ} \mathrm{C}(\mathrm{SD}$, $\left.1.3^{\circ} \mathrm{C}\right) . .^{18}$

Further studies of the effects of locally applied heat and cold on surface temperatures, underlying soft tissues, and muscles are summarized in Table $3{ }^{21-28}$ A correlation $(r=.81)$ was found between body fat mass and lowest intramuscular temperature reached during cold treatment. ${ }^{28}$

Temperatures of forearm muscles are markedly influenced by ambient temperature after cooling for 15 minutes with a cooling agent at $10^{\circ} \mathrm{C} .{ }^{29}$ Muscle temperatures decreased in both treated $\left(-2.7^{\circ} \mathrm{C}\right)$ and untreated $\left(-2.0^{\circ} \mathrm{C}\right)$ forearms of research subjects. However, at an ambient temperature of $25^{\circ} \mathrm{C}$, mean muscle temperature also decreased by $2.2^{\circ} \mathrm{C}$ and $2.1^{\circ} \mathrm{C}$ in the forearms of control subjects.

Studies of changes in blood flow during cold treatment have yielded contradictory results: significant increase, ${ }^{30}$ significant decrease, ${ }^{26}$ and absence of significant change ${ }^{31}$ have been reported. Blood flow does not seem to be altered during short-wave diathermy or infrared treatment. ${ }^{31}$

The pain threshold of healthy subjects is increased by both heat and cold. ${ }^{27,32}$ Joint stiffness is increased by cold ${ }^{33}$ and decreased ${ }^{33}$ or unchanged ${ }^{34}$ by heat.

\section{STUDIES IN PATIENTS WITH RA AND OA}

\section{Temperature in Joints and Skin}

In 1949, Hollander and Horvath published their first results on intraarticular temperature measurements. ${ }^{19,35,36}$ Forty-two internal temperature determinations in the knee joint and overlying skin surface and two in elbow joints were obtained in 31 arthritis patients and four controls. In the presence of active RA, the highest joint temperature was $37.4^{\circ} \mathrm{C}$ and the highest surface temperature was $35.6^{\circ} \mathrm{C}$. Mean temperatures were $34.1^{\circ} \mathrm{C}\left(\mathrm{SD}, 1.6^{\circ} \mathrm{C}\right)$ and $32.7^{\circ} \mathrm{C}(\mathrm{SD}$, $1.8^{\circ} \mathrm{C}$ ), respectively. In $\mathrm{OA}$, the mean surface temperature was $32.2^{\circ} \mathrm{C}\left(\mathrm{SD}, 1.1^{\circ} \mathrm{C}\right)$ and mean joint temperature was $34.4^{\circ} \mathrm{C}\left(\mathrm{SD}, 0.5^{\circ} \mathrm{C}\right)$. A correlation $(r=.65)$ was found between recorded surface and intraarticular temperatures. Comparable results were found by others in synovitis, ${ }^{19,20} \mathrm{OA},{ }^{20}$ and $\mathrm{RA}^{17,19,20,37}$ (Table 2).

\section{Influence of Movement}

The effects of active and passive non-weightbearing motion on joint temperature have been reported in three studies. ${ }^{19,35,36}$ In two healthy subjects, mean intraarticular temperatures increased by $0.7^{\circ} \mathrm{C}$. In one case of degenerative joint disease, an increase of $0.7^{\circ} \mathrm{C}$ was found. Five measurements in RA patients yielded an average temperature increase of $0.3^{\circ} \mathrm{C} .{ }^{36}$

\section{Influence of Applications}

Experimental studies in RA patients show that locally applied heat increases and cold decreases the temperature at the skin surface and in superficial tissue. ${ }^{26,38}$ However, there is controversy concerning the effects on intraarticular temperature.

Heating the lower extremities with infrared radiation for 30 minutes results in a slight increase in joint temperature. ${ }^{35}$ Short-wave diathermy for 20 minutes increases surface temperature more than intraarticular temperature. Mean increases of $4.3^{\circ} \mathrm{C}$ and $3.2^{\circ} \mathrm{C}$ in the joint and $5.4^{\circ} \mathrm{C}$ and $4.0^{\circ} \mathrm{C}$ on the surface have been observed. ${ }^{35,36}$ After 15 minutes of microwave treatment, joint temperature increased by $4.0^{\circ} \mathrm{C}$ in one study ${ }^{35}$ and $2.9^{\circ} \mathrm{C}$ in another, ${ }^{36}$ and surface temperature increased by $3.1^{\circ} \mathrm{C}$ and $2.8^{\circ} \mathrm{C}$.

Application of hot packs for 4 minutes invariably results in an increase in surface temperature and a decrease in intraarticular tempera- 
Table 3: Effects of Physiotherapy in Healthy Subjects

\begin{tabular}{|c|c|c|c|c|c|c|c|c|}
\hline Modality & Reference & $\begin{array}{c}\text { Change in } \\
\text { Skin } \\
\text { Temperature } \\
{\left[{ }^{\circ} \mathrm{C}\right]}\end{array}$ & $\begin{array}{l}\text { Change in } \\
\text { Tissue } \\
\text { Temperature } \\
\left.\text { ( }{ }^{\circ} \mathrm{C}\right)\end{array}$ & $\begin{array}{l}\text { Change in } \\
\text { Muscle } \\
\text { Temperature } \\
\left({ }^{\circ} \mathrm{C}\right)\end{array}$ & $\begin{array}{c}\text { Change in } \\
\text { Intraarticular } \\
\text { Temperature } \\
\left({ }^{\circ} \mathrm{C}\right)\end{array}$ & $\begin{array}{l}\text { Blood } \\
\text { Flow }\end{array}$ & $\begin{array}{l}\text { Pain } \\
\text { Thres- } \\
\text { hold }\end{array}$ & $\begin{array}{c}\text { Joint } \\
\text { Stiffness }\end{array}$ \\
\hline Ice & Oosterveld et a $\left.\right|^{18}$ & $-16.4 \dagger$ & & & $-9.4 \dagger$ & & & \\
\hline Ice & Belitsky et al ${ }^{24}$ & -12.0 & & & & & & \\
\hline Ice & Belitsky et al ${ }^{24}$ & -9.9 & & & & & & \\
\hline Ice & Waylonis $^{25}$ & -19.2 & & & & & & \\
\hline Ice & Bugaj $^{27}$ & $4.0 / 39.4^{*}$ & & & & & + & \\
\hline Ice & Wyper et $a^{31}$ & & & & & + & & \\
\hline Ice & Benson et $\mathrm{al}^{32}$ & & & & & & & + \\
\hline Nitrogen & Oosterveld et al ${ }^{18}$ & $-15.0 \dagger$ & & & $-4.1 \dagger$ & & & \\
\hline Cold pack & Schmidt et al ${ }^{23}$ & -12.0 & & & & & & \\
\hline Cold pack & Belitsky et a| ${ }^{24}$ & -7.3 & & & & & & \\
\hline Cold pack & Beste et $a^{26}$ & -6.0 & & & & $-\dagger$ & & \\
\hline Cold pack & Wolf ${ }^{29}$ & & & -2.7 & & & & \\
\hline Cold pack & Trnavsky ${ }^{30}$ & & & & & $+\S$ & & \\
\hline Cold water & Johnson et al ${ }^{28}$ & & & $-12.0 \ddagger$ & & & & \\
\hline Ice water & Wright et al ${ }^{33}$ & & & & & & & + \\
\hline Short-wave & Oosterveld et al ${ }^{18}$ & $+2.4 \dagger$ & & & $+1.4 t$ & & & \\
\hline Short-wave & Abramson et a $\left.\right|^{22}$ & +1.3 & +1.5 & +1.9 & & & & \\
\hline Short-wave & Wyper et $\mathrm{al}^{31}$ & & & & & + & & \\
\hline Short-wave & Benson et $\mathrm{a}^{32}$ & & & & & & + & \\
\hline Lignoparaffin & Oosterveld et al ${ }^{18}$ & $+8.9 \dagger$ & & & $+3.5 t$ & & & \\
\hline Paraffin & Borrell et a $\left.\right|^{21}$ & & & +4.5 & +7.5 & & & \\
\hline Paraffin & Abramson et $\mathrm{al}^{22}$ & +13.0 & +4.4 & +1.0 & & & & \\
\hline Paraffin & Abramson et $a^{22}$ & +13.5 & +6.2 & +3.2 & & & & \\
\hline Paraffin & Abramson et $\mathrm{al}^{22}$ & +13.0 & +5.5 & +2.4 & & & & \\
\hline Fluido & Borrell et $\mathrm{al}^{21}$ & & & +5.3 & +9.0 & & & \\
\hline Hot water & Borrell et a $\left.\right|^{21}$ & & & +4.3 & +6.0 & & & \\
\hline Heat pack & Abramson et $\mathrm{al}^{22}$ & +10.2 & +5.3 & +1.1 & & & & \\
\hline Wet heat & Abramson et $\mathrm{a}^{22}$ & +6.4 & +5.4 & +1.8 & & & & \\
\hline Ultrasound & Abramson et $\mathrm{a}^{22}$ & +0.9 & +1.4 & +0.9 & & & & \\
\hline Hot pack & Schmidt et al ${ }^{23}$ & +3.0 & & & & & & \\
\hline Infrared & Wyper et $\mathrm{al}^{31}$ & & & & & $=$ & & \\
\hline Infrared & Wright et al ${ }^{33}$ & & & & & & & - \\
\hline Heat & Yung et a $\left.\right|^{34}$ & & & & & & & $=$ \\
\hline
\end{tabular}

* Mean temperature measured at the end of treatment.

+ , insignificant increase; - , insignificant decrease; $=$, no change.

$+P \leq .01$.

$\mp P \leq .05$.

$\S P \leq .001$.

ture. Application of ice packs for the same time increased joint temperature; maximum changes occurred within the first 2 minutes. ${ }^{19}$ Surface heating was believed to decrease intraarticular temperature by shunting blood to the dilated superficial vessels and away from the inflamed synovial tissue; surface cooling did the reverse. Applying warm paraffin to joints for 25 minutes caused a sharp increase in surface temperature and a delayed but marked increase in temperature within the joint ${ }^{36}$ (Tables 4 and 5).
Later studies have produced results that are at least partially incompatible with those just described. In one, a magnetrode (a machine capable of heating deep tissue by means of an electromagnetic field) was used to treat five patients with classical RA and active inflammation of the knee for 60 minutes. Mean intraarticular temperature increased from $36.6^{\circ} \mathrm{C}$ (SD, $\left.0.8^{\circ} \mathrm{C}\right)$ to $42.0^{\circ} \mathrm{C}\left(\mathrm{SD}, 0.9^{\circ} \mathrm{C}\right)$; mean surface temperature increased from $33.7^{\circ} \mathrm{C}\left(\mathrm{SD}, 0.9^{\circ} \mathrm{C}\right)$ to $37.2^{\circ} \mathrm{C}\left(\mathrm{SD}, 1.9^{\circ} \mathrm{C}\right) .{ }^{39}$ Others found that 
Table 4: Effects of Physiotherapy in Patients With Inflammatory Joint Disease-Cold Applications

\begin{tabular}{|c|c|c|c|c|c|c|c|c|c|}
\hline Modality & Reference & $\begin{array}{c}\text { Change in } \\
\text { Skin } \\
\text { Temperature } \\
\left({ }^{\circ} \mathrm{C}\right)\end{array}$ & $\begin{array}{c}\text { Change in } \\
\text { Intraarticular } \\
\text { Temperature } \\
\left({ }^{\circ} \mathrm{C}\right)\end{array}$ & $\begin{array}{l}\text { Blood } \\
\text { Flow }\end{array}$ & Pain & $\begin{array}{l}\text { Joint } \\
\text { Stiff- } \\
\text { ness }\end{array}$ & $\begin{array}{l}\text { Inflam- } \\
\text { mation } \\
\text { Activity }\end{array}$ & $\begin{array}{c}\text { Grip } \\
\text { Strength }\end{array}$ & $\begin{array}{c}\text { Joint } \\
\text { Function }\end{array}$ \\
\hline Cold pack & Beste et $a^{26}$ & -4.9 & & + & & & & & \\
\hline Cold pack & Hollander et al ${ }^{35}$ & & +1.2 & & & & & & \\
\hline Cold pack & Hollander et al ${ }^{36}$ & -4.1 & +1.2 & & & & & & \\
\hline Cold pack & Schmidt et al ${ }^{64}$ & & & & & & - & & \\
\hline Ice massage & Grant $^{44}$ & & & & - & & & & + \\
\hline Ice massage & Melzack et al ${ }^{54}$ & & & & - & & & & \\
\hline Cold air & Oosterveld et al $\left.\right|^{37}$ & $-22.8 \dagger$ & $-3.3 \dagger$ & & & & & & \\
\hline Cold air & Hoeft ${ }^{45}$ & $24.0 / 75.2^{*}$ & & & - & & & & $=$ \\
\hline Cold air & Hoeft ${ }^{45}$ & $23.5 / 74.3^{*}$ & & & $=$ & & & & $=$ \\
\hline Cold air & Jansen et $a^{46}$ & -14.0 & & & - & & & & + \\
\hline Cold air & Heijde et al 50 & $-8.9 \dagger$ & & & - & & & + & \\
\hline Cold air & Jonderko et $a^{51}$ & & & & - & & & & + \\
\hline Ice & Oosterveld et a $\left.\right|^{37}$ & $-16.2 \dagger$ & $-6.4 \dagger$ & & & & & & \\
\hline Ice & Liman et $a^{42}$ & - & & + & & & & & \\
\hline Ice & Halliday Pegg et al ${ }^{47}$ & & & & - & - & & & $=$ \\
\hline Ice & Clarke et al $\left.\right|^{49}$ & & & & $-\ddagger$ & $-\ddagger$ & & & $+\ddagger$ \\
\hline Ice & Heijde et al ${ }^{50}$ & $-6.2 \dagger$ & & & & & & + & \\
\hline Ice & Kirk et a ${ }^{52}$ & & & & - & - & $=$ & & + \\
\hline Ice & Bulgen et $\mathrm{al}^{57}$ & & & & - & & & & + \\
\hline Ice & Williams et al ${ }^{59}$ & & & & - & & & & + \\
\hline Cold & Arman et al ${ }^{41}$ & & & - & & & & & \\
\hline Cold & Klawunde ${ }^{63}$ & $20.0^{*}$ & & & & & & & + \\
\hline
\end{tabular}

* Mean temperature measured at the end of treatment.

$t$, insignificant increase; - insignificant decrease; $=$, no change.

† $P<.001$.

$\mp P<.05$.

30-minute applications of hot packs at $42^{\circ} \mathrm{C}$ increased mean intraarticular temperature significantly from $35.2^{\circ} \mathrm{C}\left(\mathrm{SD}, 1.5^{\circ} \mathrm{C}\right.$ ) to $36.4^{\circ} \mathrm{C}$ $\left(\mathrm{SD}, 1.0^{\circ} \mathrm{C}\right){ }^{40}$ Surface and joint cavity temperatures did not return to their initial values until 55 minutes after heating stopped.

Recent investigations in our clinic yielded comparable results. Seventy-one measurements of intraarticular temperature in arthritic patients showed a significant increase of $1.7^{\circ} \mathrm{C}$ $\left(\mathrm{SD}, 1.2^{\circ} \mathrm{C}\right)$ after superficial lignoparaffin treatment, a decrease of $6.4^{\circ} \mathrm{C}\left(\mathrm{SD}, 2.8^{\circ} \mathrm{C}\right)$ after application of ice chips, and a decrease of $3.3^{\circ} \mathrm{C}$ $\left(\mathrm{SD}, 1.6^{\circ} \mathrm{C}\right)$ after treatment with nitrogen cold air. In 6 of 19 measurements in the ice chipstreated group and in 6 of 17 measurements in the nitrogen-treated group, there was an initial increase in intraarticular temperature. In the lignoparaffin-treated group $(n=20)$, there was an initial decrease in intraarticular temperature in two cases. We observed no significant tem- perature changes during placebo treatment using a short-wave diathermy apparatus. ${ }^{37}$

Although evidence from the current literature is not unequivocal, intraarticular temperature appears to increase after application of local heat and decrease after application of local cold.

\section{Clinical Effects of Application}

The effects of heat and cold on blood flow through various tissues reported for patients with inflammatory joint diseases are as inconsistent as those reported for healthy subjects. Some have found that superficial heat increases blood flow and that local cold decreases it, ${ }^{41}$ and others have found a slight increase in blood flow after or during cold application. ${ }^{26,42}$ The effect of short-wave diathermy on circulation in quiescent rheumatoid knees $(n=13)$ and acutely inflamed joints $(n=5)$ also has been studied. ${ }^{43}$ In quiescent arthritis, an average increase of 
Table 5: Effects of Physiotherapy in Patients with Inflammatory Joint Disease-Heat Applications

\begin{tabular}{|c|c|c|c|c|c|c|c|c|c|}
\hline Modality & Reference & $\begin{array}{c}\text { Change in } \\
\text { Skin } \\
\text { Temperature } \\
\left({ }^{\circ} \mathrm{C}\right)\end{array}$ & $\begin{array}{l}\text { Change in } \\
\text { Intraarticular } \\
\text { Temperature } \\
\left({ }^{\circ} \mathrm{C}\right)\end{array}$ & $\begin{array}{l}\text { Blood } \\
\text { Flow }\end{array}$ & Pain & $\begin{array}{l}\text { Joint } \\
\text { Stiff- } \\
\text { ness }\end{array}$ & $\begin{array}{l}\text { Inflam- } \\
\text { mation } \\
\text { Activity }\end{array}$ & $\begin{array}{c}\text { Grip } \\
\text { Strength }\end{array}$ & $\begin{array}{c}\text { Joint } \\
\text { Func- } \\
\text { tion }\end{array}$ \\
\hline Short-wave & Hollander et a $\left.\right|^{35}$ & +5.4 & +4.3 & & & & & & \\
\hline Short-wave & Hollander et $\mathbf{a}^{36}$ & +4.0 & +3.2 & & & & & & \\
\hline Short-wave & Endres et $a^{38}$ & + & & & & & & & \\
\hline Short-wave & Clarke et al ${ }^{49}$ & & & & $-\S$ & $-\S$ & & & $+\S$ \\
\hline Short-wave & Quirk et al55 & & & & $-\S$ & & & & $+\S$ \\
\hline Short-wave & Danz et $a^{60}$ & $+\xi$ & & & & & & + & \\
\hline Short-wave & Hamilton et al ${ }^{61}$ & & & & & & & + & + \\
\hline Short-wavet & Harris $^{43}$ & & & - & & & & & \\
\hline Short-waveł & Harris $^{43}$ & & & + & & & & & \\
\hline Short-wave & Svarcová et a $\left.\right|^{56}$ & & & & - & & & & \\
\hline Microwave & Hollander et $\mathrm{al}^{35}$ & +3.1 & +4.0 & & & & & & \\
\hline Microwave & Hollander et al ${ }^{36}$ & +2.8 & +2.9 & & & & & & \\
\hline Infrared & Hollander et $\mathrm{a}^{35}$ & & + & & & & & & \\
\hline Infrared & Hollander et $\mathrm{a}^{36}$ & +3.9 & +1.7 & & & & & & \\
\hline Infrared & Hamilton et al ${ }^{61}$ & & & & & & & + & + \\
\hline Hot pack & Weinberger et $\mathrm{al}^{40}$ & $+2.4 \|$ & $+1.2 \|$ & & & & & & \\
\hline Hot pack & Hollander et $\mathrm{a}^{35}$ & & $-1.2^{\prime \prime}$ & & & & & & \\
\hline Hot pack & Hollander et $a^{36}$ & +3.9 & -0.4 & & & & & & \\
\hline Hot pack & Kirk et al ${ }^{52}$ & & & & - & - & $=$ & & + \\
\hline Paraffin & Hollander et a $\left.\right|^{35}$ & + & + & & & & & & \\
\hline Paraffin & Hollander et $\mathrm{al}^{36}$ & +6.2 & +1.1 & & & & & & \\
\hline Paraffin & Oosterveld et $\mathbf{a l}^{37}$ & $-7.5 \pi$ & $+1.7 \pi$ & & & & & & \\
\hline Magnetrode & Spiegel et $\mathrm{a}^{39}$ & +3.5 & +5.4 & & & & & & \\
\hline Mud pack & Zivkovic et al ${ }^{48}$ & & & & - & & - & & + \\
\hline Heat & Mainardi et a $\left.\right|^{53}$ & & & & - & & $=$ & - & \\
\hline Ultrasound & Svarcova et al ${ }^{56}$ & & & & - & & & & \\
\hline Ultrasound & Hawkes et al ${ }^{58}$ & & & & $-\S$ & & & $+\S$ & $+\S$ \\
\hline Wax & Hawkes et al ${ }^{58}$ & & & & $-\S$ & & & $+\S$ & $+\S$ \\
\hline Wax & Hamilton et $a^{\mid 61}$ & & & & & & & + & + \\
\hline Moist heat & Williams et al ${ }^{59}$ & & & & - & & & & + \\
\hline Thermal bath & Günther et al 62 & & & & & & & & + \\
\hline Heat & Arman et $\mathrm{a}^{41}$ & & & + & & & & & \\
\hline
\end{tabular}

+ , insignificant increase; -, insignificant decrease; =, no change.

tMeasurement in acutely inflamed joints.

¥Measurements in quiescent arthritic joints.

$\S P<.05$.

$\| P<.01$.

$\pi P<.001$.

$60 \%$ was found. Acutely inflamed joints showed a mean decrease of $25 \%$. A $100 \%$ increase was found in eight normal subjects.

The beneficial influence of heat and cold on pain in joint disease is well established. ${ }^{44-59}$ Results of relevant studies are summarized in Tables 4 and 5.

Joint stiffness improves after local applications of heat or cold ${ }^{47,49,52}$ Grip strength usually improves with thermotherapy or cryotherapy. $.00,53,58,60,61$
The effect of heat applications on joint function has been examined in several studies, and improvement has been reported in nearly all cases. $48,49,52,55,58,59,61,62$ Some authors have described improvement $44,46,49,51,52,57,59,63$ or no change $e^{45,47}$ in joint function after cold applications.

\section{Influence on Pathology}

There have been few studies of the influence of heat and cold on the pathology of the 
inflamed joint. Kirk and Kersley ${ }^{52}$ and Mainardi et $\mathrm{a}^{53}$ showed that neither heat nor cold had any effect. Others have found a decrease in inflammation after 1 week of applying cryogel twice a day ${ }^{64}$ or after a series of 10 applications of warm mudpacks. ${ }^{48}$

\section{DISCUSSION}

Enzymatic activity increases with increasing temperature, resulting in increased breakdown of cartilage and other tissues. ${ }^{65}$ Therefore, treatments that elevate intraarticular temperature, such as microwave diathermy, short-wave diathermy, superficial heat, and ultrasound treatment, are unsuitable for treating active arthritis or secondary synovitis in OA ${ }^{65-67}$ Because higher temperatures lead to joint damage, a major aim of physiotherapeutic procedures in active arthritis should be to decrease joint temperature., 4,68 This can be achieved with local applications of cold lasting 20 to 30 minutes. ${ }^{69,70}$

The increased extensibility of collagen tissue at higher temperatures suggests that lost joint mobility may be regained. ${ }^{65,71-75}$ The viscoelasticity of the synovial fluid also is influenced by heat. ${ }^{76,77}$ Both effects can lead to reduction in stiffness of inflamed joints, as experienced by those who wear gloves at night. ${ }^{78,79}$

In our opinion, the reported beneficial effects of cold treatment on joint stiffness and joint function are strongly related to relief of pain during or after cryotherapy. Movements may be less painful and therefore easier to perform.

It was recently suggested that heating the joint cavity to $42^{\circ} \mathrm{C}$ with local microwave diathermy might inhibit destructive enzymes and cell proliferation in and metabolic activity of the synovial membrane. The increased permeability of the synovial membrane for nonsteroidal antiinflammatory drugs also might be beneficial. ${ }^{80}$ This hypothetical benefit is tempered by the finding that irreversible damage occurs in canine ligaments at this temperature. ${ }^{10}$

Treatment of RA patients using whole-body hyperthermia has been reported, $71,76,81$ but this therapy currently is not used in Western Europe. There are claims that whole-body hyperthermia is harmful to RA patients and that whole-body cryotherapy is preferable. ${ }^{82}$ These studies are controversial and incomplete.

\section{CONCLUSIONS}

Locally applied heat increases temperatures of the skin, superficial and deeper tissues, and joint cavity. In arthritic patients, an initial decrease in intraarticular temperature lasting 2 or 3 minutes sometimes is seen after local superficial application of heat.

Local cold application decreases temperatures of the skin, superficial and deeper tissues, and joint cavity. In arthritic patients, an initial increase in intraarticular temperature lasting 2 or 3 minutes sometimes is seen after local application of cold.

Locally applied heat and cold both reduce pain in inflammatory joint disease. Grip strength, joint stiffness, and joint function usually improve after local heat or cold therapy. The beneficial effects of exercise may be enhanced if some form of heat or cold is applied to joints and muscles beforehand; more research in this field is needed.

Joint temperature increases during movement.

It is unclear what effects heat and cold have on inflammation and blood flow in joints.

In treating active arthritis, cold applications are preferable because an increase in intraarticular temperature is undesirable. If the patient nevertheless prefers heat, as is sometimes the case, heat application should last no more than 5 to 10 minutes.

\section{ACKNOWLEDGMENT}

The authors are grateful to O. Duke MD, FRCP, and M.A.F.J.van de Laar, $\mathrm{MD}, \mathrm{PhD}$, for their suggestions and to R.J.M. Oude Nijhuis for typing the manuscript.

\section{REFERENCES}

1. Threlkeld AJ, Currier DP: Osteoarthritis; effects on synovial joint tissues. Phys Ther 68:364-370, 1988

2. Sokoloff L, Hough AJ: Pathology of osteoarthritis, in McCarty DJ (ed): Arthritis and Allied Conditions: A Textbook of Rheumatology (ed 10). Philadelphia, PA, Lea \& Febiger, 1985, pp 1377-1399
3. Feibel A, Fast A: Deep heating of joints: A reconsideration (commentary). Arch Phys Med Rehabil 57:513-514, 1976

4. Harris ED, Faulkner CS, Brown FE: Collagenolytic systems in rheumatoid arthritis. Clin Orthop 110:303-316, 1975 
5. Woolley DE, Evanson JM: Collagenase and its natural inhibitors in relation to the rheumatoid joint. Conn Tissue Res 5:31-35, 1977

6. Treadwell BV, Mankin HJ: The synthetic processes of articular cartilage. Clin Orthop 213:50-61, 1986

7. Harris ED, McCroskery PA: The influence of temperature and fibril stability on degradation of cartilage collagen by rheumatoid synovial collagenase. N Engl J Med 290:1-6, 1974

8. Castor $\mathrm{CW}$, Yaron $\mathrm{M}$ : Connective tissue activation: VIII. The effect of temperature studied in vitro. Arch Phys Med Rehabil 57:5-9, 1976

9. Mitrovic DR, Gruson M, Ryckewaert A: Local hyperthermia and cartilage breakdown: Histochemical and metabolic studies on rabbit articular cartilage in vitro. J Rheumatol 8:193-203, 1981

10. Woo SL-Y, Lee TQ, Gomez MA, et al: Temperature dependent behaviour of the canine medial collateral ligament. J Biomech Eng 109:68-71, 1987

11. Dorwart BB, Hansell JR, Schumacher HR: Effects of cold and heat on urate crystal-induced synovitis in dog. Arthritis Rheum 17:563-571, 1974

12. Wakim KG, Porter AN, Krusen FH: Influence of physical agents and of certain drugs on intra-articular temperature. Arch Phys Med 32:714-721, 1951

13. Lehmann JF, DeLateur BJ, Warren CG, et al: Heating of joint structures by ultrasound. Arch Phys Med Rehabil 49:28-30, 1968

14. Kern H, Fessl L, Trnavsky G, et al: Kryotherapie. Das verhalten der gelenkstemperatur unter eisapplikationgrundlage für die praktische anwendung. Wochenschrift 23:832-837, 1984

15. McMaster WC, Liddle S, Waugh TR: Laboratory evaluation of various cold therapy modalities. Am J Sports Med 6:291-294, 1978

16. Farry PJ, Prentice NG: Ice treatment of injured ligaments: An experimental model. NZ Med J 9:12-14, 1980

17. Haimovici N, Feibel A: Kritische bemerkungen zum thema 'therapeutische erwärmung der gelenke'. $Z$ Phys Med 10:113-123, 1981

18. Oosterveld FGJ, Rasker JJ, Jacobs JWG, et al: The effect of local heat and cold therapy on the intraarticular and skin surface temperature of the knee. Arthritis Rheum $35: 146-151,1992$

19. Horvath SM, Hollander JL: Intra-articular temperature as a measure of joint reaction. J Clin Invest 28:469-473, 1949

20. Haimovici N: Wert der direkten, intraartikulären temperaturmessung in der diagnostik der gelenkerkrankungen. Akt Rheumatol 7:188-193, 1982

21. Bortell RM, Parker R, Henley EJ, et al: Comparison of in vivo temperatures produced by hydrotherapy, paratfin wax treatment, and fluidotherapy. Phys Ther 60:1273-1276, 1980

22. Abramson DI, Tuck S, Chu LSW, et al: Effect of paraffin bath and hot fomentations on local tissue temperatures. Arch Phys Med Rehabil 45:87-94, 1964

23. Schmidt KL, Mäurer R, Rusch D: Zur wirkung örtlicher wärme- und kälteanwendungen auf die hauttemperatur am kniegelenk. Z Rheumatol 38:213-219, 1979

24. Belitsky RB, Odam SJ, Hubley-Kozey C: Evaluation of the effectiveness of wet ice, dry ice, and cryogen packs in reducing skin temperature. Phys Ther 67:1080-1084, 1987
25. Waylonis GW: The physiological effects of ice massage. Arch Phys Med Rehabil 48:37-42, 1967

26. Beste KW, Essiger H: Ultraschall-Doppler-Analyse der arteriellen blutströmung vor und nach kryotherapie. $\mathrm{Z}$ Rheumatol 43:66-74, 1984

27. Bugaj R: The cooling, analgesic, and rewarming effects of ice massage on localized skin. Phys Ther 55:11-19, 1975

28. Johnson DJ, Moore S, Moore J, et al: Effect of cold submersion on intramuscular temperature of gastrocnemius muscle. Phys Ther 59:1238-1242, 1979

29. Wolf SL: Contralateral upper extremity cooling from a specific cold stimulus. Phys Ther 51:158-165, 1971

30. Trnavsky G: Quantitative durchblutungsmessung vor, während und nach eisapplikation; zum wirkungsmechanismus der kryotherapie. VASA 8:20-22, 1979

31. Wyper DJ, McNiven DR: Effects of some physiotherapeutic agents on skeletal muscle blood flow. Physiotherapy $62: 83-85,1976$

32. Benson TB, Copp EP: The effect of therapeutic forms of heat and ice on the pain threshold of the normal shoulder. Rheumatol Rehabil 13:101-104, 1974

33. Wright V, Johns RJ: Physical factors concerned with the stiffness of normal and diseased joints. Bull Johns Hopkins Hosp 106:215-231, 1960

34. Yung P, Unsworth A, Haslock I: Measurement of stiffness in the metacarpophalangeal joint: the effects of physiotherapy. Clin Phys Physiol Meas 7:147-156, 1986

35. Hollander JL, Horvath SM: Changes in temperature produced by diseases and by physical therapy (preliminary report). Arch Phys Med 30:437-440, 1949

36. Hollander JL, Horvath SM: The influence of physical therapy procedures on the intraarticular temperature of normal and arthritis subjects. Am J Med Sci 218:543-548, 1949

37. Oosterveld FGJ, Rasker JJ: Temperature changes brought about in arthritic knees by local treatment with heat and cold. (in press)

38. Endres U, Callies R: Differenzierte kurzwellentherapie und hauttemperaturänderungen bei patienten mit Rheumatoid-Arthritis. Z Physiother 35:167-172, 1983

39. Spiegel TM, Hirschberg J, Taylor J, et al: Heating rheumatoid knees to an intra-articular temperature of 42.1 $1^{\circ} \mathrm{C}$. Ann Rheum Dis 46:716, 1987 (abstr)

40. Weinberger A, Fadilah R, Lev A, et al: Intraarticular temperature measurements after superficial heating. Scand J Rehab Med 21:55-57, 1989

41. Arman M, Fricke R, Liman W: Vergleichende venenverschlussplethysmographische untersuchungen nach kryound thermotherapie bei chronischer polyarthritis. Z Phys Med 9:70-72, 1980

42. Liman W, Fricke R, Taghawinejad M, et al: Arterielle durchblutung unter kryotherapie bei chronischer polyarthritis. Z Phys Med Baln Med Klim 11:196-201, 1982

43. Harris R: Effect of short wave diathermy on radiosodium clearance from the knee joint in normal and in rheumatoid arthritis. Arch Phys Med Rehabil 42:241-249, 1961

44. Grant AE: Massage with ice (cryokinetics) in the treatment of painful conditions of the musculoskeletal system. Arch Phys Med Rehabil 45:233-238, 1964

45. Hoeft G: Schmerzmessungen nach kaltgastherapie am knie. Z Phys Med Baln Med Klim 15:309, 1986 (abstr) 
46. Jansen U, Fricke R: Aenderung der hauttemperatur unter lokaler kaltluftherapie $\left(-175^{\circ} \mathrm{C}\right)$ bei kontrollpersonen und bei patienten mit chronischer polyarthritis. $Z$ Phys Med Baln Med Klim 15:308-309, 1986 (abstr)

47. Halliday Pegg SM, Littler TR, Littler EN: A trial of ice therapy and exercise in chronic arthritis. Physiotherapy $55: 51-56,1969$

48. Zivkovic M, Cvjetkovic S, Jovic D: Effects of thermotherapy on acute phase reactants in rheumatoid arthritis and ankylosing spondylitis. Arthritis Rheum 29:57, 1986 (suppl)

49. Clarke GR, Willis LA, Stenner L, et al: Evaluation of physiotherapy in the treatment of osteo-arthrosis of the knee. Rheumatol Rehabil 13:190-197, 1974

50. Heijde D van der, Riel $P$ van, Oosterhof $J$, et al: Koude-lucht-en ijstherapie; een prospectief vergelijkend onderzoek bij patiënten met reumatoide arthritis. (Cold air and ice therapy; a prospective compative study in patients with rheumatoid arthritis). Ned T Fysiother 99:40-42, 1989

51. Jonderko G, Galaszek Z, Rosmus I, et al: Erfahrungen uber die anwendung der kaltlufttherapie bei chronisch entzündlichen gelenkerkrankungen. Z Phys Med Baln Med Klim 15:309-310, 1986 (abstr)

52. Kirk JA, Kersley GD: Heat and cold in the physical treatment of rheumatoid arthritis of the knee. Ann Phys Med 9:270-274, 1968

53. Mainardi CL, Walter JM, Spiegel PK, et al: Rheumatoid arthritis: Failure of daily heat therapy to affect its progression. Arch Phys Med Rehabil 60:390-393, 1979

54. Melzack R, Jeans ME, Stratford JG, et al: Ice message and transcutaneous electrical stimulation: comparison of treatment for low-back pain. Pain 9:209-217, 1980

55. Quirk AS, Newman RJ, Newman KJ: An evaulation of interferential therapy, short wave diathermy and exercise in the treatment of osteo-arthrosis of the knee. Physiotherapy 71:55-57, 1985

56. Svarcová J, Trnavsky K, Zvárová J: The influence of ultrasound, galvanic currents and shortwave diathermy on pain intensity in patients with osteoarthritis. Scand $\mathbf{J}$ Rheumatol 67:83-85, 1988 (suppl)

57. Bulgen DY, Binder AI, Hazleman BL, et al: Frozen shoulder: Prospective clinical study with an evaluation of three treatment regimens. Ann Rheum Dis 43:353-360, 1984

58. Hawkes J, Care G, Dixon JS, et al: Comparison of three physiotherapy regimens for hands with rheumatoid arthritis. Br Med J 290:1016, 1985

59. Williams J, Harvey J, Tannenbaum H: Use of superficial heat versus ice for the rheumatoid arthritic shoulder: A pilot study. Physiother Can 38:8-13, 1986

60. Danz J, Callies R: Differenzierte kurzwellentherapie und hauttemperaturänderungen bei patienten mit Rheumatoid-Arthritis. Z Physiother 35:81-84, 1983

61. Hamilton DE, Bywaters EGL, Please NW: A controlled trial of various forms of physiotherapy in arthritis. $\mathrm{Br}$ Med J 28:542-544, 1959

62. Günther R, Spath P, Egg D, et al: Das verhalten der komplementkomponenten $\mathrm{C} 3$ und $\mathrm{C} 4$, des C-reaktiven proteins und der blutsenkungsgeschwindigkeit zur aktivitätskontrolle bei arthritiskranken wăhrend thermo-hydrotherapie. Z Rheumatol 37:33-39, 1978
63. Klawunde G: Klinische und experimentelle erfahrungen bei der anwendung der kryotherapie mit tiefkühlkompressen in der behandlung schwerer funktioneller gelenkerkrankungen. Zschr Physiother 28:201-205, 1976

64. Schmidt KL, Mäurer R, Rusch D: Zum verhalten der hauttemperatur über entzündeten kniegelenken unter täglicher kryotherapie. Z Phys Med 9:58-59, 1980

65. Lehmann JF, de Lateur BJ: Heat and cold in the treatment of arthritis, in Lehman JF (ed): Therapeutic Heat and Cold, Baltimore, MD, Williams \& Wilkins, 1982, pp 315-378

66. Feibel A, Fast A: Deep heating. Arch Phys Med Rehabil 58:233, 1977 (letter)

67. Jessop ID: Arthrosis deformans, in Mason M, Currey HLF (eds): Klinische reumatologie (Clinical rheumatology). Leiden: Stafleu's wetenschappelijke uitgeversmaatschappij BV, 1973, pp 227-248

68. Amundson H: Thermotherapy and cryotherapyEffects on joint degeneration in rheumatoid arthritis. Physiother Can 31:258-262, 1979

69. Schmidt KL: Kältebehandlung rheumatischer erkrankungen: wirkungsweise, verfahren und therapeutische prinzipien. Akt Rheumatol 6:88-94, 1981

70. Menninger $\mathbf{H}$, Burkhart $\mathbf{H}$, Hering $\mathrm{B}$, et al: Biochemische grundlagen der kältetherapie bei rheumatische erkrankungen. Z Phys Med 9:65-66, 1980

71. Conradi E: Physiotherapie der entzündlichen und degenerativen gelenkkrankheiten. Z Arztl Fortbild 81:442446,1987

72. Lehmann JF, Warren CG, Schram SM: Therapeutic heat and cold. Clin Orthop 99:207-245, 1974

73. Warren CG, Lehmann JF, Koblanski JN: Elongation of rat tail tendon: Effect of load and temperature. Arch Phys Med Rehabil 52:465-475, 1976

74. Lehmann JF: Deep heating. Arch Phys Med Rehabil 58:232-233, 1977 (letter)

75. Patil JJP: Deep heating. Arch Phys Med Rehabil $58: 232,1977$ (letter)

76. Schmidt KL, Ott VR, Rocher G, et al: Heat, cold and inflammation (a review). Z Rheumatol 38:391-404, 1979

77. Kennedy AC: Joint temperature. Clin Rheum Dis 7:177-188, 1981

78. Rasker JJ, Peters HJG, Boon KL: Influence of weather on stiffness and force in patients with rheumatoid arthritis. Scand J Rheumatol 15:27-36, 1986

79. Oosterveld FGJ, Rasker JJ: The effect of pressure gradient and thermolactyl control gloves in arthritic patients with swollen hands. Br J Rheumatol 29:197-200, 1990

80. Weinberger A, Fadilah R, Lev A, et al: Deep heat in the treatment of inflammatory joint disease. Med Hypotheses 25:231-233, 1988

81. Licht S: Physical therapy in arthritis, in Lehmann JF (ed): Therapeutic Heat and Cold (ed 3). Baltimore, MD, Williams \& Wilkins, 1982, pp 263-269

82. Yamauchi T: Whole body cryo-therapy is method of extreme cold $-175^{\circ} \mathrm{C}$ treatment initially used for rheumatoid arthritis. Z Phys Med Baln Med Klim 15:311, 1986 (abstr) 